\title{
Šime Pilić
}

\section{Osječke sociološke teme}

\section{Matica hrvatska, ogranak 0sijek, 0sijek, 2019., 168 str.}

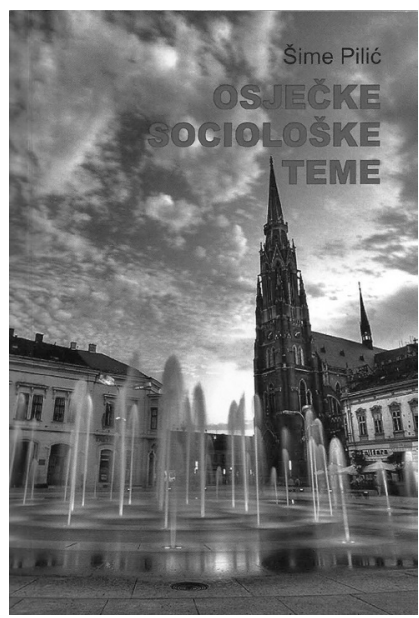

Knjiga Osječke sociološke teme prof. dr. sc. Šime Pilića sastoji se od dvaju dijelova i od pet poglavlja. Knjiga je komponirana tako da sadrži Predgovor, dva dijela (u prvom tri, a u drugom dva poglavlja), Kazalo imena (kojih ima više od 180), Popis tablica (kojih je 39), Podatke o tekstovima u knjizi i naposljetku Bilješku o autoru.

Iza svakog poglavlja navedena je literatura (najbrojnija u drugom poglavlju - 33, a najmalobrojnija u petom poglavlju koje ima 19 bibliografskih jedinica i u Predgovoru - 11, ili ukupno u knjizi navode se 142 bibliografske jedinice).

Treba još istaknuti da se iza svakog od pet poglavlja donosi sažetak u prijevodu na engleski jezik. Svako poglavlje ima veći ili manji teorijski uvod i u većini napomenu o metodologiji rada.

Prvi dio knjige naslovljen "Od tradicije i nasljeđa do razvoja i granica" sadrži tri poglavlja. U prvom poglavlju "Seljani dviju regija o životu i tradiciji na selu” donose se empirijski rezultati istraživanja i kompariranja dviju regija, Dalmacije i Slavonije. Pored definicija regije, sela i tradicije, tu se još nalaze i zanimljivi sadržaji vezani uz život na selu između poljoprivrede i procesa približavanja gradu, kao i stavovi seljana o elementima tradicije u radu i životu na selu. Istraživanja su potvrdila da se i danas nastavlja trend napuštanja sela i poljoprivrede, tako da je sve manje nositelja tradicije na selu, kao što je sve manje i stanovništva uopće u ruralnim prostorima Hrvatske.

U Hrvatskoj se od kraja 2. svjetskog rata stanovništvo na selu stalno smanjuje i danas je njegov udio (40\%) manji nego u Europi (43\%). Jednako se smanjuje udio poljoprivrednog stanovništva u ukupnom. Tako se trend smanjivanja nastavlja od $50 \%$ pedesetih godina na 9\% 1991. te samo 2\% u 2011. godini. 
Stavovi seljana o elementima tradicije u radu i životu na selu ispitivani su pitanjima kao što su: je li utjecaj tradicije veći na selu nego u gradu, odnos prema zemlji i poljoprivredi, odnos prema radu, religiji, održavanju običaja u svakodnevnom životu, odnos prema susjedima, prema spolu, obitelji. Potom se donose rezultati odgovora na set pitanja o seoskoj zajednici i solidarnosti, životu na selu u percepciji seljana i dr. Ispitanici u Dalmaciji npr. dvostruko više nego slavonski smatraju da ljudi na selu žive u zajedništvu i povjerenju.

U drugom poglavlju "Nasljeđe i razvoj: jučer i danas" autor ukratko naznačava kakav je bio razvoj hrvatskog društva u drugoj polovici 20. stoljeća, a kakav je danas, tj. u posljednjim desetljećima u globalizirajućem svijetu. Negacija stečenog nasljeđa gospodarskog i ukupnog društvenog razvoja hrvatskog društva pretvorila se u deindustrijalizaciju. Proces pretvorbe i privatizacije izazvao je lomove gospodarstva, preraspodjelu društvenog bogatstva i promjene društvene stratifikacije.

Ilustrirajući nalaze o nasljeđu i razvoju hrvatskog društva donosi se nekoliko primjera navedene problematike. Tvornica električnih strojeva "R. Končar" 1946. godine imala je manje od 900 zaposlenih, a 1986. bilo ih je 23 500, od kojih je 3900 imalo VŠS i VSS, 137 magistara i 23 doktora znanosti. Ili Prvomajska 1946. godine zapošljava 180 radnika, a 1989. zapošljavala je 7440 radnika i bila najveći proizvođač alatnih strojeva u Hrvatskoj i bivšoj Jugoslaviji. Autor navodi i primjer IPK Osijek, karakterističan za Slavoniju, koji je zapošljavao gotovo 15000 zaposlenika, a od čega je malo što ostalo. Navodi i najnoviji primjer u gospodarskoj grani brodogradnje, gdje brodogradilište Uljanik u Puli, nakon gotovo stoljeća i pol manje-više uspješnog poslovanja, odlazi u stečaj. Takvih primjera ima više.

Dalje se govori o kretanju stanovništva Hrvatske (koje je raslo od 1948., od 3780 000 na 4499000 do 1991. godine, njegovoj dobnoj strukturi, kretanju BDP-a, (ne) zaposlenosti i dr.).

U odjeljku 4.5. drugog poglavlja donosi se nekoliko zanimljivih činjenica vezanih uz nekoliko egzaktnih podataka o broju nezaposlenih i zaposlenih u Hrvatskoj. Broj nezaposlenih u 2008. godini bio je 255 491., a 2018. godine 177 973. Broj zaposlenih u 2008. bio je 1536 166., a 2018. godine 1430 273. Prema tome, u navedenom je desetljeću 105893 manje zaposlenih i to je negativan rast od 6,9\%, unatoč tome što je nezaposlenost smanjena za više od 77 000. Pad zaposlenosti u navedenom razdoblju imaju sve županije u Republici Hrvatskoj, izuzev Zadarske županije i Grada Zagreba.

U ovom poglavlju autor donosi i vrlo zanimljiv podatak glavnog ekonomskog analitičara Europske banke za obnovu i razvoj (EBRD), prof. dr. sc. Sergeja Gurijeva, na temu promjena u svijetu, posebice promjena u svijetu rada, kao i problema starenja stanovništva s kojim se suočava Europska unija. U tom kontekstu za Hrvatsku se može 
reći da ima tri velika problema: (1) stanovništvo je sve starije, (2) iseljavanje radno sposobnog stanovništva uzima maha, (3) hrvatski su građani u prosjeku slabijeg zdravlja nego stanovništvo razvijenih zapadnih zemalja, tj. starih članica Europske unije.

Poglavlje "Sudbina ljudi i otvorenih granica" - treće po redu - bavi se problematikom emigracijskih kretanja iz Hrvatske u europskom kontekstu, s posebnim osvrtom na iseljavanje iz Slavonije. Autor navodi da je u prvom i drugom desetljeću 21. stoljeća došlo do migracijskih kretanja u svijetu takvih razmjera da je ono s punim opravdanjem nazvano "stoljeće migracija". Tako u stoljeću migracija u države Europske unije ilegalno useli, prema procjenama, oko 400000 migranata godišnje. U tom poglavlju nalaze se važni sadržaji vezani uz temeljne pojmove o otvorenoj i zatvorenoj granici kao i o sudbinama tih migranata. Autor iznosi i podatak Svjetske banke, koja predviđa da će se u sljedećih desetak godina pojaviti više od 100 milijuna tzv. klimatskih izbjeglica, tj. onih koji će se pomicati uslijed velikih promjena klime i njezinih posljedica. No, to se može spriječiti ukoliko se na ovoj jedinoj (našoj) planeti pravovremeno poduzmu odgovarajuće mjere u svezi s tim klimatskim promjenama.

Drugi dio knjige "Podrijetlo nastavnika i njihovo vrednovanje sa stajališta učenika" sadrži sljedeća poglavlja: "Vrednovanje odnosa nastavnik - učenik sa stajališta učenika" i "Regrutiranje srednjoškolskih profesora u postsocijalističkoj Hrvatskoj”.

Ako sociolozi obrazovnog sustava promatraju odnose u razrednom odjelu i u školi u interakcionističkoj perspektivi ili u kojoj drugoj, činjenice govore da će se odnosima nastavnik - učenik, i obratno, povećavati sve veća pažnja u istraživanjima. Time se u svijetu sve više bavi mikrosociologija, odnosno "nova sociologija obrazovanja".

I prema Nacionalnoj strategiji za pravo djece (od 2014. do 2020. godine) danas se u Hrvatskoj predviđa cilj povećanja sudjelovanja djece u procesima donošenja odluka od interesa za njihov odgoj i obrazovanje. Kada je riječ o vrednovanju odnosa nastavnik - učenik, autor ističe kako se i u Hrvatskoj sve više vode diskusije o tome što će školi demokracija, a što će demokraciji škola.

Rezultati istraživanja iznijeti u 4. poglavlju "Vrednovanje odnosa nastavnik - učenik sa stajališta učenika” pokazuju da učenici osnovnih škola ocjenjuju društveni odnos u školi (između nastavnika i učenika) više demokratskim nego srednjoškolci. Autor dokazuje da nisu ustanovljeni pomaci u demokratskim odnosima u školi, ako se to stanje usporedi sa stanjem prije promjena 90-ih godina prošloga stoljeća u hrvatskom društvu. Razlike se pokazuju u porastu autoritativnog odnosa u školi i smanjenju anarhičnoga - barem tako učenici vrednuju taj odnos.

U petom, posljednjem poglavlju "Regrutiranje srednjoškolskih profesora u postsocijalističkoj Hrvatskoj” iznose se podaci o nekim obilježjima nastavničke profesije iz 
šireg empirijskog istraživanja $(\mathrm{N}=586)$. Autor razmatra iz kojih se društvenih grupa regrutiraju profesori srednjih škola u hrvatskom društvu. Najveći je broj njih iz radničkih, potom iz službeničkih te poljoprivrednih obitelji. Iznose se također rezultati o obrazovanju roditelja, obrazovna i profesionalna struktura supružnika srednjoškolskih profesora kao i tip naselja u kojima stanuju te odnos domicilnih i doseljenih profesora i još dosta drugih zanimljivih podataka o nastavničkoj profesiji.

Autor ističe kako se danas u hrvatskom društvu javlja paradoks obrazovanja. Sve je manje učenika (u novije vrijeme i studenata), a sve više nastavnika. Takav je omjer pedagoški poželjan, ako se promatraju učinci nastave (poželjan je rad u manjim grupama). No, tu se može postaviti pitanje sa stajališta ekonomike društvenih djelatnosti, posebno ekonomike obrazovanja. Takva istraživanja, ističe autor, danas u našoj zemlji upravo nedostaju.

Recenzenti ove knjige, dr. sc. Antun Šundalić (redoviti profesor u trajnom zvanju) i dr. sc. Željko Pavić (izvanredni profesor)s osječkog Sveučilišta pohvalili su knjigu i istaknuli njenu veliku vrijednost. Šundalić smatra da je knjiga izvorna, kako svojom tematikom tako i autorovim pristupom. Navodi da autor ukazuje na aktualne probleme hrvatskog društva koji su isprepleteni u samoj mijeni društva i društvenog razvoja u cjelini. Probleme analizira kroz aktualne procese deruralizacije i detradicionalizacije, kroz istraživanje regionalnih razlika i uvjetovanosti promjena, kroz učinke utjecaja globalnih integracijskih procesa na otvaranje hrvatskog društva i migracijske promjene. Knjiga Osječke sociološke teme vrijedan je doprinos boljem razumijevanju tranzicije hrvatskog društva.

Pavić smatra da knjiga predstavlja originalan doprinos hrvatskoj sociologiji, ali i društvenim znanostima u cjelini. Ističe kako crvena nit koja se provlači knjigom predstavlja bogato sociološko iskustvo i znanje autora, koji prikupljene podatke čini životnim i stavlja ih u jasan teorijski kontekst, potičući čitatelja na sociološku refleksiju. Ističe da se knjiga čita lako, ali i s osjećajem da se bavi onim temama o kojima ovisi daljnji društveni razvoj, a možda i demografski i kulturni opstanak hrvatskog društva.

Velimir Karabuva

Split 